Témoigner Témoigner. Entre histoire et mémoire

Getuigen Revue pluridisciplinaire de la Fondation Auschwitz

$123 \mid 2016$

Traduire le témoignage

\title{
The Italian Military Internees in Germany during World War II: Repatriation, Memory, Denial
}

\section{Sabrina Frontera}

\section{Q OpenEdition \\ 1 Journals}

\section{Electronic version}

URL: https://journals.openedition.org/temoigner/5447

DOI: 10.4000/temoigner.5447

ISSN: 2506-6390

Publisher:

Éditions du Centre d'études et de documentation Mémoire d'Auschwitz, Éditions Kimé

\section{Printed version}

Date of publication: 1 October 2016

Number of pages: 156-167

ISBN: 987 2-9600926-4-6

ISSN: 2031-4183

\section{Electronic reference}

Sabrina Frontera, "The Italian Military Internees in Germany during World War II: Repatriation, Memory, Denial", Témoigner. Entre histoire et mémoire [Online], 123 | 2016, Online since 02 November 2021, connection on 04 November 2021. URL: http://journals.openedition.org/temoigner/5447 ; DOI: https://doi.org/10.4000/temoigner.5447 


\section{The Italian Military Internees in Germany during World War II Repatriation, Memory, Denial}

THE DIFFICULT WAY TO FREEDOM

A fter the armistice of 8 September, more than 650,000 Italian soldiers, who had refused to fight for the Axis, were disarmed by the Wehrmacht and deported to the Reich for forced labour. Deprived of the "Prisoner of War" status, they were classified as "Italian military interninternational organizations could not reach their Oflag and Stalag cross and other despite the Geneva Convention agreements, soldiers were employed in factorie practically as slaves. Until February 1944, German and RSI authorities offered the pration Italian mithe meant that they could leave the camps and return to Italy. The majority of the IMI - more than 600,000 men - refused, preferring to be interned over becoming part of the Fascist army

In the summer of 1944, following an agreement (“Civilization") between Hitler and Mussolini, the military internees were declared civil workers. Internees were forced to sign a statement in order to be declared civilians. Since most of the Italians refused to sign the documents, the procedure was cancelled and they were forcedly given the status of civilians. Although international laws had forbidden the employment of foreign officers, many of them were forced to work along with the soldiers (Hammermann 2002: Schreiber 1990).

Despite the hardships of the whole imprisonment period, the memoirs and diaries of the internees describe the last months of detention as the worst:
Saturday 10 February 1945. It's raining. I am fine... Hunger keeps me from my sleep. All is quiet. The Russians don't move. The English and Americans don't move. We are down. FFFFFFFFFF. Nothing happens, nothing ever happens! I'm left alone, even time abandoned me.

Friday 23 February 1945. It is raining - I am fine - It's getting tougher and tougher FFFFFFFF

We are rotting I'm miserable, I'm hungry, I want to smoke, I'm cold, I don't receive any news, I can’t bear it anymore! (Guareschi 2008, 458-460)

Today 12 March 1945. 18 months have passed... I never thought I would stay for such a long time, in a country so far away... And it still goes on. Every day I hear the air alerts; I keep hearing the noise of firing machine guns. There is not enough food, I cannot satisfy my hunger. (Ceciliato 2005, 70)

The IMI imagined the arrival of the Allies and the formal liberation of the camps to be the end of their anguishes and sufferings. Unfortunately things turned out differently. Instead of being repatriated straight away, the Allied Supreme Head Quarter decided in February 1945 that the internees, whowere considered displaced persons, would remain in the camps awaiting further interrogation. ${ }^{4}$

Most of the internees therefore were repatriated only in the autumn of 1945. IMI describe this delay as intolerable for many reasons: first of all they were considered displaced persons and not former prisoners of war. Moreover, they were initially given a treatment similar to that reserved for German civilians and enemy camps. Only after June 1945, the British and Americans started to consider the Italian internees as Allied displaced persons, allowing them the same help and rights, except for the repatriation priority, whereas the French and Russians carried on their discriminating policies. The French treated the IMI who had fought against France as their own prisoners of war (POW) and employed all former internees as civil workers. ${ }^{5}$ The USSR considered IMI Allied POW as well, and conducted thorough research

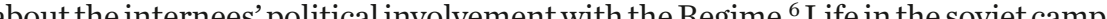
about the in

The IMI interpreted the absence of Italian commissions, the length of their waiting before repatriation, and the lack of information and news from their country as evidence of the Italian government's indifference. The fear of being accused of collaborationism in Italy grew, together with a deep disbelief in the institutions, in the new political parties and in their rhetoric:

I believed in righteousness and I was wrong. According to the latest rumours, the voluntary workers are treated better than us and they are going home before we are. So this is our reward. I realize now that our sacrifice was useless.

[...]

I dreamt that I was home and being treated like dirt. I believe I am going to be terribly humiliated. And I am pessimistic about the future. (Guareschi 2008, 527)
(3) We further refer to Pietro Testás 'Relazione originale' from
the ANEl archives: attachment 64, from prof Enrico Ziloc to the talian Camp Command and attachment 91 , from lieutenant
colonel Pietro Testa to the Germ Berrardi), Wietzendorf 24 March 1945. See also Hammermann 2002 325-337; Schreiber 1990, $743 f f$.
translations from Italian are the author's. (4) Historical archives of the
Ministry of Foreign Affairs (A931-1E), Affari Politici (AA PP) 1931-1945. Prigionierie Intern dai russi sul fronte orientale:
ministero degli Esteri, Appunto ministero degli
per la segreteria perl la segreteria
February 1945 . (5) Central state archives (ACS),
Ministero della Difesa, Stato Maggiore dell Lsercito, Ufficio

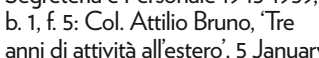
1948; ACS, Acc, UA, DP, shelf 116, tape 130E, f. 10000/164/2609 Repatriation of tlatians from France
(vol 2): S. . Ten Cataldi Ambrogio 6 December 1945; ASMAE, $A$ A (5) Pi. from the Ministry of Foreign affairs to the Italian Embassy in London,

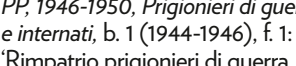
'Rimpatrio prigionieri di guerra
(Pdg) einternati Parte general sf. 4 Militarie cill the generale, dei tedeschil: from the Embassy in Paris to the Ministry of Foreign
affairs in Paris, 10 May 1945 ; see

(6) ASMAE, AA PP 19311945, Pdg e internati, b. 31: $\mathrm{f}$
Militari italiani liberati dai russ sul fronte orientale': from the the
the Ministry of Foreign affaris
in Mosca, 20 April 1945 ; bid. in Mosca, 20 April 1945; lbid,

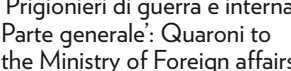
the Ministry of Foreign (7) Ibid,.f.' 'Prigionieri di guerra e 


\section{THE ROOTS OF OBLIVION}

Their fears became reality when the internees crossed the Italian border: the treatment they received in care centres was very much below their expectations Everyday life proved to be difficult too: finding a job and consequently living a normal life was practically impossible (Bistarelli 2007; Frontera 2009; Labanca 2000; Visan 2006). The IMI were also disappointed by the deceptive behaviour of institution and parties, which had expressed solidaritybuthad not taken adequate care of their in Prime minister Ferruccio Parri and Foreign minister Alcide De Gasperi described internees as brave soldiers that had endured concentration camps for having refused to cooperate with the Nazis, but the IMI who had been forced workers in the Reich were considered collaborationists by the Italian institutions. ${ }^{9}$ This contradiction would last, and it would affect the lives of the IMI as well as how they were remembered by their families and community.

In the Brenner care centres, IMI were questioned about their behaviour on 8 September and in the camps. All officers had to complete a brief report and soldiers had to fill out a form containing a few simple questions: place and date of arrest, employment (type of employment if relevant), and employment starting date. No only did War minister Alessandro Casti recommend fast and brief questionings, only did War but also reports containing the sol over, the questionnaire only queried about the circumstances of the arrest but not about the orders received by the internees on 8 September. There were neithe questions about the behaviour of entire military units nor about the proposal of collaboration with the Nazi-Fascist army, while there were many about work: what the IMI's job was, when he started working, and whether or not he had worked on a voluntary basis. The answers would have a tremendous impact on the IMI's lives, however. According to an order sent on 15 May 1945 by War minister Alessandro Casati to territorial commandos, the military internees who had worked in the Reich before 31 December 1944 should be considered volunteers and, like the members of Nazi-Fascist forces, would not receive their arrears.

This contradictory behaviour can be explained only if we consider the Italian contemporary social and historical background. When the IMI finally returned home in the autumn of 1945, the apex of the Purging process had ended. Both civilians and politicians expressed the wish to move forward, and to transcend past internal divisions (Woller 1997; Lanaro 1992, 11ff; Bistarelli 2007, 21ff). Even veterans were encouraged by the institutions to work "silently" for reconstruction and social peace (see Rusconi 30 May 1945; 21 July 1945). "Veterans could not expect anything from the Italian people", wrote La Voce della Patria, a newspaper edited for veterans and soldiers, "everyone in Italy, women, old men and children stood in the face of war and could be considered veterans as well" (Firmino 1945,1). An analysis of the press coverage at the time sugests that all veterans were strongly advised by the press covare at the time suggests that all veterans were strongly advised by the institutions to form a single association, even the ones who, "struck by a political
spell", had fought on the "opposite battlefield" (Marchi 6 July 1945). Mussolini and a few top people of the party were considered the only ones responsible for the war while ordinary Italians were described as "victims of a political deceit" who had nothing to do with Fascism and the "Nazi war" (Marchi 14 June 1945; 6 July 1945; Mondini 4 November 1945).

This clear distinction between Italian and Fascist responsibilities had many aims: first, to promote the myth of the Resistance as a mass experience in which the great majority of Italians had taken part; second, to present Italy as a country that had fought that had fough and din the end, dherd, to meet the need of many Italians to forget the past, the war, and its painful consequences An in-depth investigation of IMI's files was undesirable because it would imply investigation into the first three years of the war, into the role played by Italy, and into the long and painful process which had started in 1942 and had caused the collapse of the Regime. An investigation into the armistice and the responsibilities of the Supreme Headquarter in the defeat of 8 September would also be necessary (Frontera 2015; Peli 2004, 193; Zani 2009, 127-151; Oliva 2005, 79).

The brief questionnaire War Minister Casati drafted for the IMI avoided all these topics. However, the minfor the IMI avoided ister's decision entailed that many soldiers were denied their wages, even if they had never been in a position to refuse work. The preconception that IMI were collaborationists would persist for a long time, even at an institutional level. This context discouraged the internees from sharing their memories. Not surprisingly, testimonies would become rare between 1945 and 1948, an the battle for recognition was instead fought by associations such as The National Committee of Veterans of Prison Camps and the National Association of Former Internees in Germany. While the first one was open to Internees in German every for established for militar to civil internees.

In February 1946, following the former internees' protests and the opposition of the territorial comman dos, War Minister Manlio Brosio asked the Premiership to review the decision to deny wages to the internees. The minister asserted that:

The behaviour of the soldiers should be judged according laws that did not forbid them from working during detention. Being denied the POW status and being classified as internees has meant the infringe-
- Drawing by Carlo Maggio,

Wietzendorf Oflag 83, 18
April 1945 .

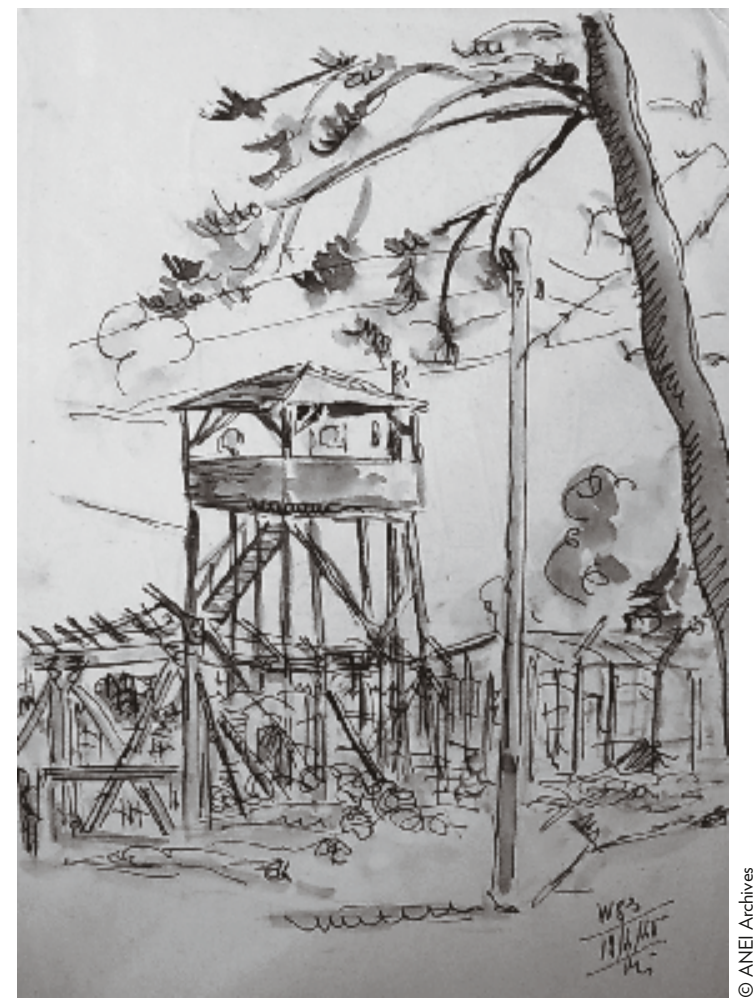




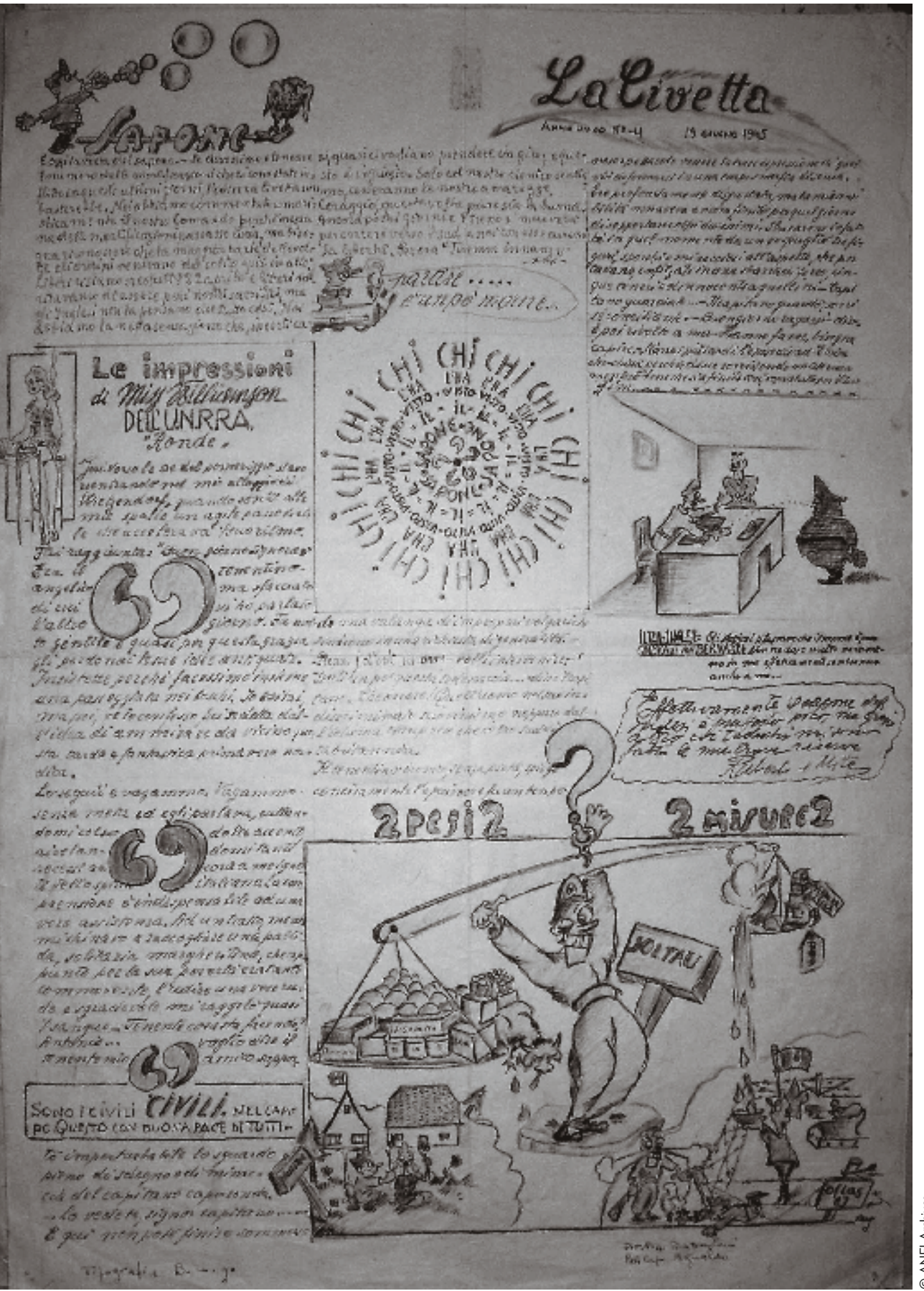

ment of the IMI's rights, in the Reich as well as in Italy by our own institutions, which are depriving IMI of their wages. ${ }^{12}$

The Premiership, the Ministry of Post-war Assistance, the War Ministry and the Treasury Ministry played an important role in the two year discussion that followed Brosio's proposal. In the Autumn of 1946, Prime Minister De Gasperi proposed to pay the wages to the soldiers, and to carry on more in-depth investigations only on officers. This proposal was refused by the War Minister, who advocated per acated the cancell tio who objected to the payments. Bertone wrote that it was impossible to pay IMI wages for economic reasons and underlined that "to review the decision about IMI would mean to review the wider political approach in matter of collaborationism and anticollaborationism"13. Even War Minister Luigi Gasparrotto, who agreed with the payments, underlined that new investigations on IMI history would have been inadequate (Frontera 2009, $40^{14}$ ).

In 1946, conservative parties, and leftist parties that identified themselves with - and had to defend the legitimacy of - the armed resistance, felt that a deep inquiry into the history of IMI was not worthwhile. Maintaining unity and peace became a priority, as well as upholding the idea of an Italy that had always been hostile to Fascism. The speech given by Minister of Post-war assistance Emilio Sereni at the National congress of ANEI in November 1946 is an example of this dominant way of thinking. In his speech, the minister reacted to ANEI's request to be recognized of thinking. In his speech, the minister reacted to ANEI's request to be recognized
as a foundation and to have its own delegates in the local post-war assistance offices. as a foundation and to have its own delegates in the local post-war assistance offices. ANEI, he asserted:

I know your pain, because I experienced it personally, and Italy must show consideration for the former internees' experiences [...]

Italy cannot be rebuilt just by the antifascists, that would be a great mistake. There are too few of us. The influence of Fascism is still strong, corrupting, widespread: we must put a stop to whatever remains of it. ${ }^{15}$

Sereni's speech ended with a call for all veterans to unite. According to the minister, internees and partisans should rather "distance themselves from Fascist elements" working within and leading the National Association of former Combatants (ANC), instead of creating new organizations: "Internees [...] should hold hands, not build barriers, and they should work together with other veterans towards reconstruction."

THE 1950S: BETWEEN RECOGNITION AND DENIAL

Nevertheless, the acknowledgment of the ANEI became effective in $1948^{16}$, even if a thorough investigation into IMI's pasts was never conducted. The Government's
(12) ANS, PCM, 1944-1947,
b. 1.2.1. f. 62496: Ministry of War to PCM, 18 February
1946. See AUSSME. DS, 4235, , .' Prigionieri di Guerra 1945: Ministry of War, Rorme. 1 November 1945. ACS, $P C$ S.f. 4-2.

(13) ANS, PCM, 1944-1947, b. 1.2.1, . 62496: Ministry of Treasury to PCM, Rom
22 December 1946 .

(14) ANS, PCM, 1944-1947, 6. 1.2.1. . . 22496 : War Minister (15) ANEl archives, Congressi
Nazionali, ‘erbale dei lavori Illd Congresso nazionale ANEI',
Rome, 24-26 November 1946 . (16) Law $\mathrm{Dpr} n^{\circ} 403,2$ April 
favourable decision was influenced by several elements that were listed by the Premiership Undersecretary Giulio Andreotti in a letter to post-war Assistant Undersecretary Martino in July 1947. They included the presence of a great number of former internees; the membership of civil internees in ANEI (impossible in ANC and Anpi); and most importantly, the fact that internees were not connected to any political party and adopted a positive attitude towards the government, which was confirmed by ANEI president Riccardo Orestano. ${ }^{17}$ The great number of internees and their devotion to the government would become a crucial factor in view of ees a dhe the elections. As Bistarelli underlined, the measures in favour of the veterans and the extra subsidies suggested "the possibility of a political exchange between the political majority and the veteran's leaders; this exchange would guarantee some advantages to the veterans' associations, and the political control of the majority over the veterans organization" (Bistarelli 2007, 257).

With the legal acknowledgment of ANEI, the matter of the arrears was also settled. An interministerial commission decided that further inquiries were not necessary, certified that the measure was based just on an order and not on laws, and approved the payments to soldiers and officers. ${ }^{18}$ After two years of debate, the IMI issue was well-known. However, in spite of the association's support of the government - confirmed by the election of Paride Piasenti, a Christim democratic the deputy, as president of the ANEI - and its positive influence on the memory of the internment, prejudices and stereotypes persisted. The analysis of bills and officia publications between 1948 and the 1950s highlights that IMI were formally recognized as antifascists but their tribulations were underestimated and their story neglected, especially if compared with that of the partisans.

An example of this attitude towards IMI is the book La riscossa dell'esercito [The Army's Revenge] edited by Ettore Scala and published by the General Staff Historical Office in 1948. The aim of the book - funded by the Ministry of Defencewas to "retrace the history and the drama of the Italian army during the war and to re-evaluate the army's efforts and sacrifice" (Scala 1948, preface). Large part of the book focused on the Armistice but mentioned only the episodes of open fire battles against the Nazi. against the Nazi. Very few pages were dedicated to the first three years of the war and even less (eighteen in total) to POW. Fifteen out of these eighteen pages were dedicated to IMI, adnired by the author for their "tenacious" and "silent" perseverance (329). According to Scala, the IMI passed through a more terrible ordeal than the ones endured by those who died in battles. Nevertheless, IMI glory was closer to martyrdom than to military honour - two very different things.

The comparison of IMI to martyrs who suffered horrible pains was persistent. It resulted from interpretations that, instead of taking into account the historical context of Fascism and Nazism, considered them as pure evil. The comparison of internment to martyrdom was often used with a negative connotation, as the debate in the bill for the War Medol (between 1951 a 1954) clearly shows. Firstly still believed that imprisonment was IMI's own fault, and that their work in Germany was a voluntary collaboration. Furthermore, one member of the parliamentary com- mission mentioned the "unclear circumstances of IMI's capture"19. The Delegate of the National Blue Ribbon Association, Eugenio Spiazzi, thought IMI deserved the medal but, according to him, "it would be better if we awarded a 'suffering medal' for the internees instead of a War Medal, because they gave up the fight, allowing the Germans to capture and deport them" ${ }^{20}$. Even though the medal was granted to the IMI in 1953, the decision not to examine the responsibilities of the highest military ranks in the armistice influenced the collective and institutional memory: the idea of an heroic army slowly dissipated and one of soldiers who had given up the fight became more common (Aga Rossi 2006; Peli 2004).

Responsibilities were considered from a very partial point of view and internment was taken into consideration only in relation to suffering. "Sacrifice on behalf of freedom", "heroic holocaust of lives": those were the words used by Italian President Gronchi in the messages sent to the ANEI Congress on 1955, 1958 and 1961. ${ }^{21}$ Gronchi described the internees not just as survivors, though, and this was a big step forward. He recognized that pain and sacrifices were endured by IMI in the name of freedom. Nevertheless, IMI were still described as the victims of "inescapable inhumanities and brutalities", referring to Fascism and Nazism.

\section{CONSTRUCTING THE MEMORY OF THE RESISTANCE, REWRITING HISTORY}

Gronchi's message is characteristic of a new take on Italian collective memory of the Resistance and WWII. It was the government's aim to create a representation of the past that could unite a country that was undergoing social and political changes. Resistance, in particular, was described as the ideological foundation of new collaborations between PSI and DC (Merolla 2004; 2006). Many political and social actors were suspicious of this turnaround, however.

ANEI presented itself "as supporter and defender of national honour and freedom, far from partial passions and suggestions"22. At the same time, the association encouraged public knowledge of the internment supporting the publication of studThe winn The winning diary, Fronte senza Eroi [A Frontline with No Heroes], was written by a soldier, Adler Raffaelli, and is still one of the most famous documents on internment. The author described the working conditions in the Reich and eliminated some tenacious preconceptions by using a plain style to describe a situation close to slavery, and by discussing his opposition to Nazism. Raffaelli tried to preserve his human dignity and stayed loyal to his uniform. As his arguments could not be attributed to a particular political ideology, the diary was more than suitable for ANEI's purposes

This is how ANEI gained the trust of the government and became a member of the Official National Committee for the celebration of the twentieth anniversary of the Resistance ${ }^{23}$ The Committee, led by the President of the Republic, would organize the celebration following the approval of the government and of the Ministries of Defence and Public Education. It was composed by delegates from Italian Minis(19) Chamber of representatives,
Commissioni in sede legislativa,
V Commissions (Difess) $V$ Commissione (Difesa),
10 Novembre 1950, intervat 10 Novembre 1950, intervention
of Antonio Cuttitta, p. 480 . (20) Ibid, intervention of
Eugenio Spiazzi, p. 480 . (21) Archives of the Foundation
'Luigi Micheletti': Vittorio Emanuele Giuntella, Vita Astti del Congresso Nazional ANEI Trento, 1955'; Ibidi: Atti
del Congresso Nazionale ANEI del Congresso Nazionale ANEI
1958 ; Ibid.: Atti del Congresso
Nazionale ANEI Roma 29 maggio-1giungo 1964. (22) Archives of ANEI, Congressi
nazionali, Verbale dei lavori Verona, 23-25 April 1950, p. 15,
Paride Piasenti spech; ANEI, Da Merano ad Amburgo, p. 23-24. 1952. (23) The Comitee was founded
according to law $n^{\circ} 128,12$ March 1964 , Gazzetta Ufficiale 78 ,
27 March 1964 . 
tries and from the most important veterans associations. ANEI played a key role and took part in one of the five Committee's commissions called "Exhibitions and Publications" ${ }^{24}$ The events organized by ANEI were supported by the governmen and by the Vatican, and the association obtained funds for the national congress of 1964 and for the foundation of a research centre.

The congress was included in the official celebrations, and so was ANEI's exhibition "The Resistance in Nazi camps" set up in the prestigious Palazzo Brasch in Rome ${ }^{25}$ It was the aim of the exhibition to show a "different” Besistance, one in that was foug withestined to "follow moral order and serve the cause of freedon" (ANEI 1964, xv). In a lette to Angelo Salizzoni, ANEI's president Paride Piasenti pointed out that the congres and the exhibition would represent "some of the few events that can be referred to as completely ours" (of DC) from a political point of view. He confirmed that their goal was to shed a new light on the Resistance, emphasizing features that are "barely known and beyond the influences and policies of Marxism" ${ }^{26}$ In fact, as Piasent underlined, "the devotion to democracy as stated in the Constitution" was one of the main features of internment. ${ }^{27}$

ANEI worked actively to construct the memory of Resistance during the anniversary year Pis actively to conether with Maio Argent Fascism

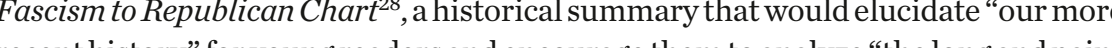
recenthistory" ful labour that gave birth to the Italian denocracy" (Conitato Nazionale 1966, 3). Internment was briefly described in the second part of the text, that discussed the reign of the South and RSI. The internees' refusal to collaborate with the Nazis was considered a "reiterated and unanimous decision, made by a huge number of men in increasingly difficult conditions. A unanimous voice that would be considered the answer to a referendum that never happened." (123)

This was a misrepresentation of the facts, because according to it, IMI could have chosen to collaborate with Nazi-Fascists at any time and not just until February 1944 This version attributed a strong political meaning to the IMI's choice and extended This versionats of the experis of IMI was recognized, but there was no in-depth analysis of their activities. Moreover, a large part of the book was dedicated to the partisans war, the Volunteers of Freedom Unit (CVL) and the Committee of National Liberation (CLN) ${ }^{29}$ Once more, Resistance was presented as "a battle in which the whole Italian population took part, an endeavour shared by every citizen" (Comitato Nazionale 1965, 21).

Even during the most important event of the anniversary on 9 May 1965 in Milan, an emphatic and unifying image of Resistance was promoted. There were no references to the Resistance as a civil and class war, and even the partisan movement was described without taking its social, cultural and political complexity into account (Chiarini 2005; Focardi 2005; Cell 2004, 2006 Oliva 2005; Pavone 1995; 1991 ne 1995; 1991; be composed only of partisans and patriots; they could not wear signs of political

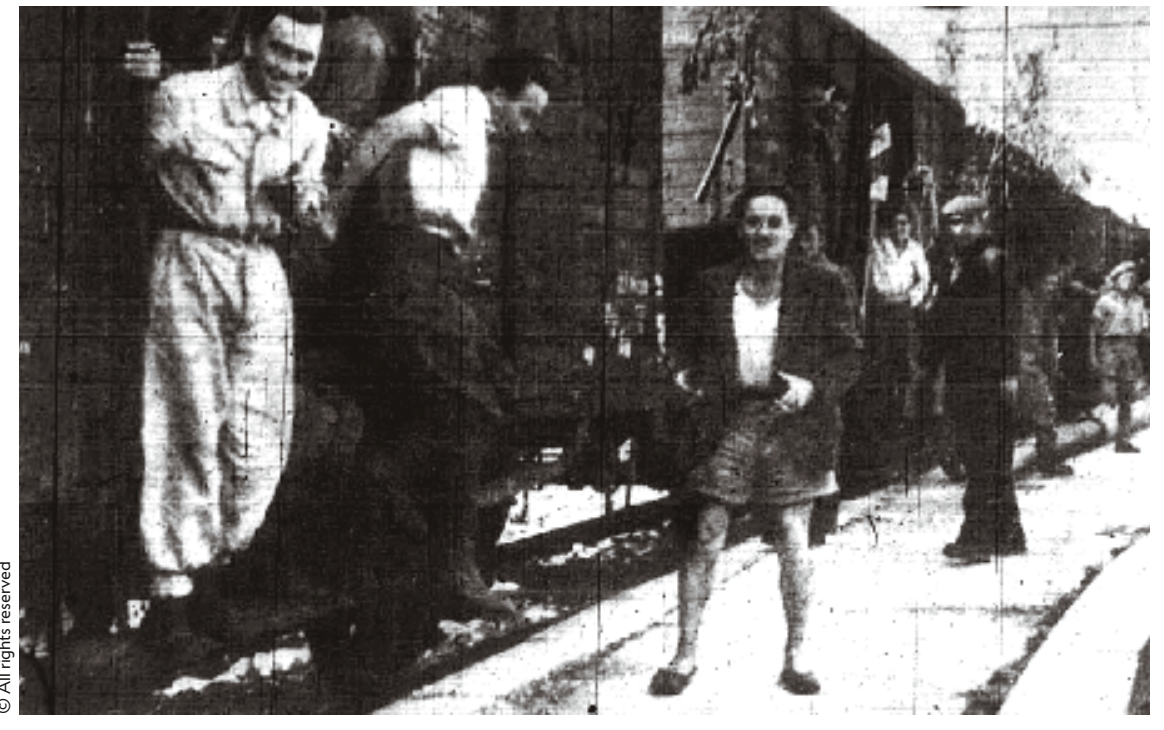

- IMI arriving in Italy. Domenica degli Italiani, supplement of $I l$

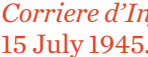

identity and the Italian flag would be the only one allowed. While the parade was supposed to demonstrate the unity of Resistance movements, ironically, internees, deportees and partisans had to march separately:

The most important requirement is the unitary spirit of the manifestation. [...] the popular revolt for freedom will present itself united with the regular armed forces that fought on their side. [...] Partisans from abroad, former deportees and internees will march separately, however. [...] Only the Italian flag is allowed, alongside medals, and all participants will wear the tricolour neckerchief. ${ }^{30}$

The instructions suggest that the celebration was not only a way to talk about the past, but also aimed at building a national identity. The only speech given that day was the one by the President Saragat, who remembered 9 May 1945 as a day to celebrate the victory of "the Nations joint in the defence of mankind, the nations that fought against the fury of those who had denied mankind and trampled on it" (Comitato Nazionale 1965,16). The Italian resistance, framed in a European context of anti-Nazist movements, was put forth as a battle in which all citizens had taken part. Fascism, on the other hand, was described as a dictatorship which had risen to power and "diverted Italy from the path it was predestined to take, given its history and its heritage" (16). This path was outlined by the Risorgimento, and was directly climax of this historical evolution (21).

Saragat added that at the same time hundreds of thousands of Italian soldiers and officers were taken into prison camps: "They refused to join the Nazist army
(30) Archives of ANEl, b.
'Comitato Ventennale Resistenza',
f. 'Ventennale 1965': Comitato Celebrazioni Ventennale della Resistenza, 'Lettera dalla giunta esecutiva ai comitati lo
Rome, 18 Appril 1965 . 
and they faced their martyrdom stoically", he said (19). It was essential that the President mentioned the internees in his speech even if there was still no real acknowledgment: in 1963, Germany refused to offer the internees a compensation intended for people persecuted by the Nazis. In order to obtain the compensation, a person had to be deported for racial, religious or ideological reasons. IMI's refusal to collaborate with the Axis was not regarded as an ideological opposition against Nazism and Fascism, and compensation was granted only to the internees who had been transferred into Straflagers.

In spite of ANEI's role in the Committee, a true recognition of the internees'

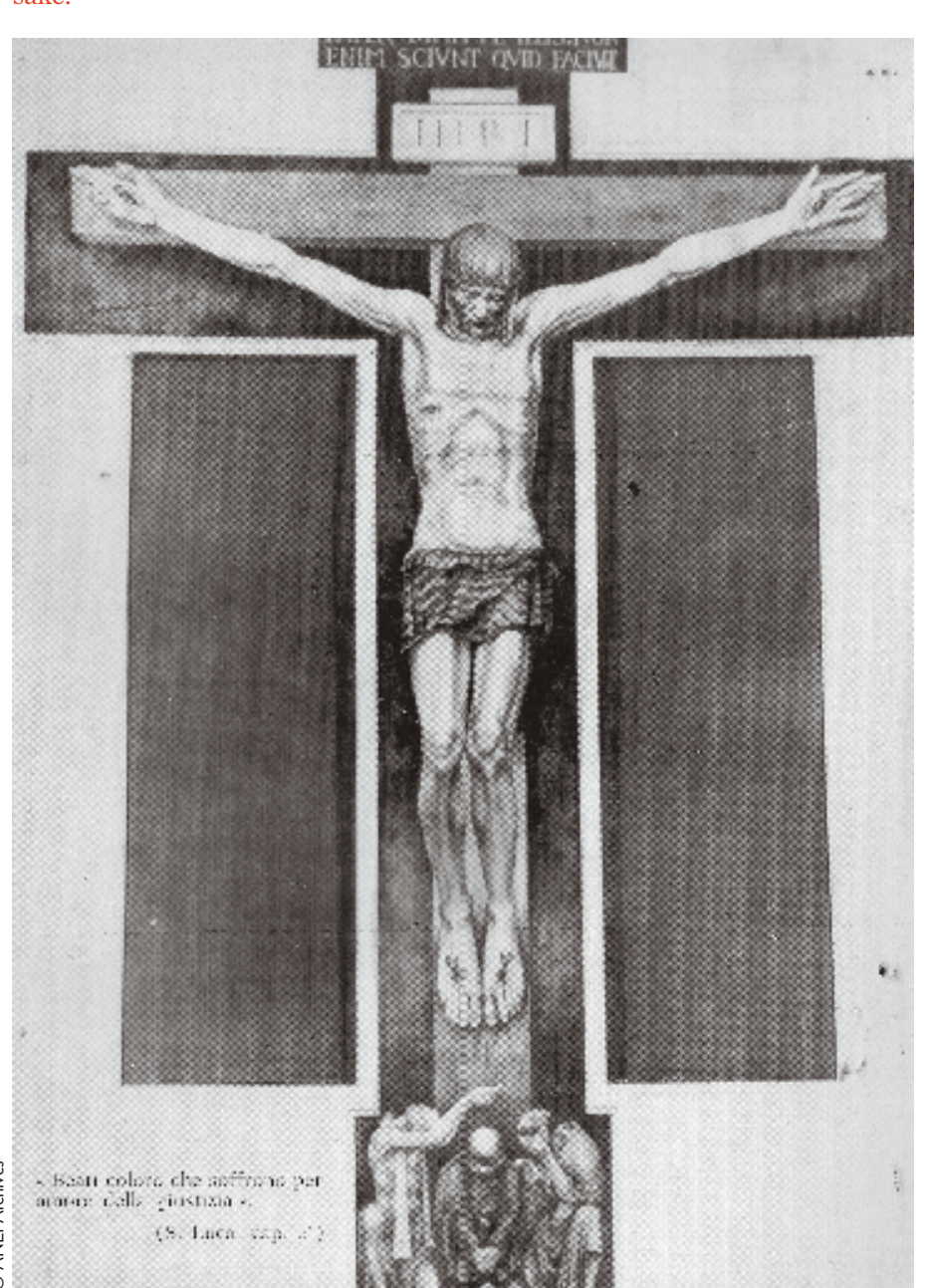

WORKS CITED

- Aga Rossi, Elena, Una nazione alll sbando. L'armistizio italiano dell's
settembre 1943 ele sue conseguenze, Bologna: II Mulino, 2006 .

- ANEI, La resistenza italiana nei lager nazisti, Rome ANEL 1964

- Bistarelli, Agostino, La storia del ritorno. I reduci italiani nel secondo

- Ceciliato, Giovanni, La mia vita prigioniera. Diario dai campi di

- Chiarini, Roberto, 25 aprile. La competizione politica sulla memoria,
Venice: Marsilio, 2005.

- Comitato Nazionale per la Celebrazione del Ventennale della Resistenza Comitato Nazionale per la Celebrazione del Ventennale della Resistenga
(ed.), Messaggio del Capo dello stato agl italiani. Milano, 9 maggio 1965 ,
Rome: Litostampa Nomentana, , 1965.

---- (ed.), L'ltalia dal fascismo alla - Firmino, Mario, 'Quarantacinque milioni di reduci', La Patria, ed. Italia
Settentrionale, 11 June 1945.

- Focardi, Filippo, La guerra della memoria. La Resistenza nel dibattito (2)

- Frontera Sabrina, 'II ritorno dei militari italiani intern
(1945-1946)', Mondo Contemporaneo 3, 2009, 5-47.

-..-, Il ritorno dei militari italiani internatiti in Germania. Dalla 'damnatio - Guareschi, Giovanni, II grande diario. Giovannino cronista del lager 19431945, Milan: Rizzoli, 2008.

- Giusti, Maria Teresa, I prigionierr italiani in Russia, Bologna: II Mulino, 2003.

- Hammermann, Gabriele, Zwangsarbreit für den "Verbündenten": die Deutschland 1943-1945, Tübingen: Niemeyer, 2002

- Labanca, Nicola (ed.), La memoria del ritorno. II rimpatrio degli internati
militari italiani (1945-1946). Florence: Regione Toscana e Anei 2000 .

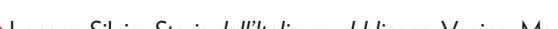
- Lanaro, Silvio, Storia dell Italia repubblicana, Venice: Marsilio, 1992. - Marchi, Riccardo, 'I diciassettemila e gl altri', La Patria, ed. Alta Italia,
14 June 1945.
-..- 'Fraternità fra i reduci' La Patria ed. Italia Settentrionale 6 July 1945 - Merolla, Marilisa, Italia 1961, Imedia celebrano il Centenario della

-.-., 'Radio italienne et mémoire de la Résistance 1958-1965', in Christian Delporte \& Denis Maréchal (eds.), Les Médias et La Libération en - Mondini, 'Soldati italiani in Russia', Illustrazione Italiana, 4 November

- Oliva, Gianni, Le tre Italie del 'az. L'alibi della Resistenza. Come abbiamo

Pavone, Claudio, Una guerra civile. Saggio storico sulla moralità della
Resistenza, Torino. Bollati Boringhieri, 1991 . -..., Alle origini dellla Repubblica. Scritit isu fascismo, antifascismo e
continuità dello Stato, Torino: Bollati Boringhieri, 1995 . - Peli, Santo, La resistenza in Italia: storia e critica, Torino: Einaudi, 2004. - Rinauro, Sandro, 'Una prigionia interminabile: gli italiani dalla detenzione nei campi francesi alla guerra d'I'Indocina. 1940-1954' in Eric Gobetti
(ed.), La lunga liberazione 1943-1945, Milano: Franco Angeli, 2007. - Rusconi, Edilio, 'Un problema spinoso', Uomo qualunque, 30 May 1945. -.-., I morti vogliono dormire', Oggi, 21 July 1945. - Scala, Ettore (ed.), La riscossa dell'esercito, Rome: Stato Maggiore
dell'Esercito, 1948. - Schreiber, Gerhard, Die italienischen Militinternierten im deutschen
Machtbereich 1943-1945. Verraten - Verachtet - Vergessen, München,
1990.

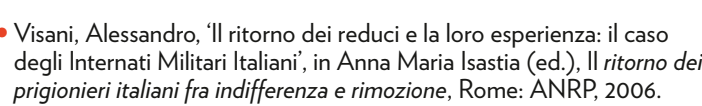
- Woller, Hans, I conti col fascismo. L'epurazione in Italia 1943-1948,
translated from the German by Enzo Morandi, Bologna: II Mulino, 1997. - Zani, Luciano, 'Il vuoto della memoria. I militari italiani internati in
Germania', in Piero Craveri \& Gaetano Quagliarello (eds.), La second guerra mondiale e la sua memoria, Soveria Mannelli: Rubbettino, 2006. -..., Resistenza a oltranza. Storia e diario di Federico Ferrari internato
militare italiano in Germania, Milan: Mondadori, 2009. 